KAZIMIERZ WOJNOWSKI

ORCID 0000-0002-1522-2568

Uniwersytet im. Adama Mickiewicza

$w$ Poznaniu

\title{
AKSJOLOGIA NORMATYWNA PRZYKAZAŃ JUDAIZMU TARJAG MICWOT - NIEKTÓRE ASPEKTY (DO) NAUCZANIA I WYCHOWANIA
}

\begin{abstract}
AвSTRACT. Wojnowski Kazimierz, Aksjologia normatywna przykazań judaizmu Tarjag micwot - niektóre aspekty (do) nauczania i wychowania [Normative Axiology of the 613 Commandments of the Judaism (Tarjag micwot) - Selected Aspects to Teach and Raise]. Studia Edukacyjne nr 57, 2020, Poznań 2020, pp. 161-176. Adam Mickiewicz University Press. ISSN 1233-6688. DOI: 10.14746/se.2020.57.11

Jewish education is based on normative axiology tarjag micwot which include ethical values and fundamental social norms, including legal values. Historically and contemporary teaching in Judaism is grounded on the values included in 613 commandments of the Jewish moral and legal axiology. The values comprised in commandments of the Judaism were borrowed from the Christian axiology, however some of them were adopted in Islam. Contemporary many values stemming from Jewish commandments appear in non-religion axiology. In order to develop knowledge, skill and competences these values are still relevant.
\end{abstract}

Key words: normative axiology, moral values, social norms, Judaism, Jewish education

Relacje międzyludzkie tworzą zbiorowości z motywów nie tylko realizacji potrzeb tożsamych czy zbliżonych, lecz także z ich odmienności konfrontujących się w związkach zależności ról i funkcji. Społeczny ład wyznaczają normy aksjologiczne stanowione w odległych już historycznie okresach, sięgających czasów antycznych, średniowiecznych, czy też bliższych współczesności, incydentalnie tworzone w teraźniejszości. Normy stanowiące o porządku spolecznym skierowane są do ludzi jako jednostek, to jest do osób, ponieważ zawierają wartości w swych różnych treściach przedmiotowych, dotyczących całości życia ludzkiego, także doświadczanego w indywidualnym istnieniu człowieka. Nakazowa lub zakazowa wymagalność respektowania norm wyraża konieczną powinność, przez co informuje ich adresata o jej przestrzega- 
niu, bowiem to określa i wyznacza wymagany porządek i spokój społeczny oraz wewnętrzny w człowieku.

Normy ujawniają wartości rozumiane jako stany rzeczy, w tym również pojmowane jako osoby ludzkie oraz relacje między nimi, a także ich z innymi pozaludzkimi istnieniami. Aksjologiczny status norm ma zatem pierwotnie regulatywne znaczenie przed utylitarnymi celami i pragmatycznymi działaniami ludzkimi. Wartości określają i wyznaczają zatem akceptowane społecznie postępowanie człowieka, wprawdzie różne wartości w perspektywie historyczno-kulturowej, jednakże uznawane jako obowiązujące w każdym obecnym tu i teraz miejsca i czasu.

W śródziemnomorskiej kulturze normatywnej dominuje historycznie ukształtowana i utrwalona aksjologia prawa rzymskiego, która historycznie wywodzi się z aksjologii reguł zwyczajowych oraz prawa obyczajowego, natomiast $\mathrm{w}$ zasadzie pozostaje ona $\mathrm{w}$ neutralności do aksjologii etycznej bądź religijnej ( $w$ tym, np. prawa objawionego). Natomiast, w pozajurydycznej sferze życia, zwłaszcza kulturowego, znaczące są wartości normatywizmu etycznego, zasad obyczajów, reguł zwyczajów, czy wierzeń religijnych, funkcjonujące w całokształcie społecznej regulatywności aksjologicznej. W kulturze judaistycznej normatywizm aksjologiczny wyrażany jest $\mathrm{w}$ formułach przykazań (micwot), ponieważ historycznie prawo żydowskie wywodzi się z religijnych regulatywów Tory (w niej prawa Mojżeszowego), również z tekstów Miszny, dla których powstania Stary Testament Pisma Świętego był podstawą oraz z tekstów Gemary, które powstawały w trzystuletnim dyskursie z tekstami Miszny, tworząc to dzieło (gamar - kończyć, tłumaczyć), obejmujące wszystkie dziedziny życia, a więc z obu tych Ksiag stanowiących podstawę treści Talmudu ${ }^{1}$. Natomiast Tarjag micwot 613 przykazań judaizmu jest zbiorem nakazów oraz zakazów tworzonych na podstawie treści zawartych w powyższych Ksiegach i Pismach oraz redagowanych w okresie środkowego Średniowiecza Rambama (Majmonides 1135-1204), wydawanych w Renesansie (Rzym 1480 r., Konstantynopol 1536 r., Wenecja 1523 r. i tam w 1584 r. wydanie opracowanych w IX/X wieku 613 przykazań), w XVII-XVIII wiekach (Amsterdam 1649 r.) oraz czasach późniejszych (Warszawa 1817 r. i tam w 1882 r., Wiedeń 1878 r. Adolf Jellinek)².

Treści talmudyczne - wywodzące się z ksiag Miszny (jej 63 traktatów) o charakterze prawno-religijnym, to jest dotyczące nakazów i zakazów, określane halacha oraz narracje o treściach opowieści, legend, sentencji moralnych,

${ }^{1}$ Z madrości Talmudu, wybór i przekł. Sz. Datner, E. Kamieńska, Warszawa 1988, s. 19, (s. 5-57), (s. 331-369).

${ }^{2}$ Tarjag micwot 613 przykazań judaizmu oraz siedem przykazań rabinicznych i siedem przykazań dla nie-Żydów, przekł. E. Gordon, Kraków 2000, s. 6-7. Z tego wydania tekstu Tarjag micwot 613 przykazań judaizmu cytowane są w artykule przykazania (micwy). 
alegorycznych, aforystycznych, zwane hagada były i są treściami kształcenia w nauczaniu na wszystkich poziomach szkolnictwa żydowskiego, to jest od cheder (szkoła elementarna) do jesziwy w zakresach i profilach rabinicznym, talmudycznym oraz w edukacji niereligijnej, także w niejudaistycznej. Treści Gemary w tekście talmudycznym, dotyczące wszystkich sfer życia, zawierają ich poznawcze obrazowanie, stanowiące i wyrażające konteksty zasadności stosowania micw, co w edukacji wyraża się i przejawia w nauczaniu wychowującym, które przekazuje w przedmiotowych zakresach wiedzy wartości konieczne dla samorozwoju oraz ich stosowania w adekwatnych im dziedzinach praktyk społecznych. Treści talmudyczne są najbardziej sprzyjające edukacji spośród kanonów innych systemów edukacyjnych zorientowanych religijnie, bądź częściowo takich w założeniach aksjologicznych - na przykład buddyzmu, hinduizmu oraz w istniejących w nich odmian konfesyjnych. Wszakże nazwa Talmud (przeważnie określana jako słowo talmud) pochodzi od rdzenia lamad, co w języku hebrajskim znaczy "uczyć się”, "nauczanie”, szerzej - „nauka”, „studium” ${ }^{3}$. W ujęciach paradygmatycznych pedagogiki, treści talmudyczne konstytuują źródłowo zaczyny dwóch paradygmatów, to jest kształcenia oraz wychowania, mających w przeszłości, jak i współcześnie skuteczne sprawstwa w licznych, a popularnych obecnie paradygmatyzacjach - od nauki i jej wiedzy począwszy, poprzez mnogie pragmatyczne, do możliwie różnorodnych aksjonormatywnych.

Aksjologia normatywna judaizmu

posiada 613 przykazań (micwot), których treść wynika ze słów Tory. Słowo tarjag oznacza liczbę 613; jest utworzone przez zapisanie tej cyfry alfabetem hebrajskim, gdzie każda litera ma wartość liczbową (taw $=400, r e s z=200$, jud $=10$, gimel $=3$ ). Według tradycji, Mojżesz przekazał Żydom Torę z przykazaniami. Wartość liczbowa słowa Tora wynosi 611, gdy doda się do tego dwa pierwsze przykazania, które Żydzi usłyszeli bezpośrednio od Boga, stojąc pod górą Synaj - wychodzi liczba 613. Sześćset trzynaście przykazań jest podzielone na 248 nakazów (micwot ase) i 365 zakazów (micwot lo taase). Liczba 248 odpowiada tradycyjnie liczbie członków ciała ludzkiego, liczba 365 odpowiada liczbie dni roku słonecznego ${ }^{4}$.

Uporządkowania Tarjag micwot historycznie dokonywano według czterech sposobów: na święto Szawout (najstarszy dotyczący anonimowych poematów); z podziału Tory na 54 części (parasze), co odpowiadało odczytaniu jej w Szabat, a więc w całości w ciągu roku, przy czym niektóre parasze nie zawierały przykazań; grup tematycznych właściwych Dekalogowi; w układach niezależnych, w których dominuje podział micwot na: o treści pozytywnej 248 nakazów oraz

${ }^{3}$ Boska pieczęć. Mądrości Talmudu, wybór i przekł. z hebrajskiego A. Klugman, Wrocław 2000, s. 5; Z mądrości Talmudu, s. 332; Stownik wyrazów obcych PWN, red. J. Tokarski, Warszawa 1971, s. 742.

${ }^{4}$ Tarjag micwot 613 przykazań judaizmu, s. 6. 
negatywnej 365 zakazów według ich ważności ${ }^{5}$. W tekście korzystanej książki dla cytowania przykazań (micwot) są one uszeregowane według

kolejności ich występowania w Torze zgodnie z "Sefer Hachinuch" (w opracowaniu rabina Ahrona Kahana ", The Taryag Mictzovs", NY 1987/88. Cyfra z lewej strony to numer micwy według miejsca w Torze (zgodnie z "Sefer Hachinuch"), mała cyfra z prawej strony to kolejny numer micwy według listy dołączonej do "Sefer Tehilim" z 1882 r. Obok pojawia się [zamieszczony jest - K.W.] numer micwy według układu Rambama $\mathrm{z}$ "Sefer Hamicwot" oznaczony odpowiednio (...) + (dla micwy pozytywnej) lub (...) (dla micwy negatywnej) ${ }^{6}$.

W poniżej cytowanych micwach wszystkie cyfry są jednakowej wielkości, lecz w niezmienionym porządku występowania według wskazanych wyżej Ksiag i Pism.

Przedstawione poniżej micwy występują w kolejności, w jakiej są zapisane w cytowanej pracy Tarjag micwot 613 przykazań judaizmu... ${ }^{7}$. Jednakże, ze względu na konieczność ich wybiórczej prezentacji nie są pogrupowane zakresem przedmiotowym/dziedzinowym ich odniesienia, co wydaje się powinno być, choć takie grupowanie micw równie zasadnie może być kwestionowane, bowiem ich struktura porządkowa jest już pierwotnie określona w systemie i sposobie ich kolejnościowego występowania w Księgach Tory oraz w źródłowym uporządkowaniu wskazanym $\mathrm{w}$ poprzednim akapicie. Ponadto, treści Tarjag micwot wywodzą się z tekstów Ksieggi przykazań - Sefar Hamicwot Rambamba Majmonidesa XII w., czy Wielkiej księgi przykazań - Sefar hamicwot hagadol Szymona Kario z okresu gaonów IX-X w., bądź Księgi Wychowania - Sefar hachinuch Arona Halevi XIII w. Przyjęcie ujęcia egzegetycznego uzasadniałoby agregatyzację dziedzinową micw, czego nie zamierzono $w$ niniejszym opracowaniu. Ponadto, micwa w judaizmie, jako wywodząca się z Ksiag Tory, bowiem zawierają one tarjag micwot, ściśle przynależy do konkretnej z Pięciu Ksiag Tory $\mathrm{i}$ jest przejawiana $\mathrm{w}$ akcie religijnym, a przez ten akt spełnia się $\mathrm{w}$ dziedzinach pozareligijnej aktywności. Pięcioksiag Tory tworzą: Bereszit (Genesis) zawiera 3 micwy, Szemot (Exodus) zawiera 111 micw, Wajikra (Leviticus) zawiera 247 micw, Bamidbar (Numeri) zawiera 52 micwy, Dewarim (Deuteronomium) zawiera 200 micw, Szewa Micwot Derabanan (siedem Przykazań Rabinicznych) zawiera 7 micw, Szewa Micwot Bne Noach (siedem Przykazań [dla] potomków Noego) zawiera 7 micw. Wyboru cytowanego micw dokonano ze względu na treść zawartych $\mathrm{w}$ nich wartości, przedstawiając te, które zawierają możliwie niekonfesyjną

5 Tamże, s. 6, 8 .

${ }^{6}$ Tamże, s. 8, 9.

7 Zapis cytujący ze stron 10-121 jest pisany kursywa, bez cudzysłowów, z pominięciem skrótów i numerów Ksiag Tory (Gen: numeracja), (Ex: numeracja), (Num: numeracja), (Lev: numeracja), (Deut: numeracja) oraz nazw w języku hebrajskim nie mających znaczenia dla treści przykazania, tj. nie zmieniających jego treści. 
neutralność oraz historycznie i obecnie powszechną stosowalność poza judaizmem, i występują w systemach aksjologii normatywnej etycznej oraz prawnej, a także przekazywanych w edukacji oraz stosowanych w praktyce moralnej i jurydycznej, co też nie wyczerpuje możliwości ukazywania klarowności ich treści sacrum i profanum w refleksjach pedagogicznych.

\section{Z Księgi BESZERIT (GENESIS)}

1. Przykazanie "bycia płodnym i rozmnażania się". 1. + 212. Jest to przykazanie nakładajace na mężczyznę obowiązek ożenienia się i spłodzenia dzieci.

\section{Z Księgi SZEMOT (EXODUS)}

33. Przykazanie szanowania ojca i matki. 27. + 210.

34. Nie [wolno] zabić niewinnego. 34. -289. Publiczne zawstydzenie człowieka, również traktowane jest jak rozlew krwi.

35. Nie [wolno] odstaniać nagości kobiety zamężnej. 35. - 347. Dotyczy to przypadku cudzołóstwa z kobieta mająca status (...) kobiety zamężnej (należącej do jakiegoś mężczyzny).

36. Nie [wolno] porwać człowieka. 36. - 243.

37. Nie [wolno] świadczyć fatszywie. 37. - 285.

38. Nie [wolno] pożądać rzeczy należacej do bliźniego. 38. - 265.

47. Przykazanie dla sądu, aby wykonać wyrok śmierci przez uduszenie (....). 45. - 227. Za sześć przestępstw wymierzana była kara śmierci przez uduszenie: za cudzołóstwo z kobieta zamężna; za skaleczenie rodzica; za porwanie Żyda; za fałszywe proroctwo; za prorokowanie w imię bożków; za niepostuszeństwo mędrca (...) autorytetowi Sanhedrynu.

48. Nie [wolno] uderzyć ojca ani matki. 60. - 319. Nawet w samoobronie, chyba, że rodzic chce zabić.

49. Przykazanie [nakładania] grzywien. 46. + 236. Kary pieniężne nakładane (...) za skrzywdzenie kogoś obejmują: (...) - stała szkodę na ciele; (...) - ból; (...) - wydatki na leczenie; (...) - utrata zarobku z powodu choroby; (...) - zawstydzenie.

50. Przykazanie dla sąu, aby wykonać wyrok śmierci przez ścięcie mieczem (...) 47. + 226. Kara ta była wymierzana za: morderstwo; zbiorowe batwochwalstwo $w$ mieście.

54. Przykazanie ukarać złodzieja grzywna. 50. + 239. (...).

56. Przykazanie, aby osadzić szkody wywołane [spowodowane] ogniem. 52. + 241. (...).

58. Przykazanie, aby rozsądzić w sądzie [sprawy] pomiędzy skarżącym a oskarżanym. 54. +246.

60. Przykazanie, aby rozsadzić w sądzie [w sprawie] pożyczajacego. 56. + 244. (...).

61. Przykazanie, aby rozsądzić w sądzie [w sprawie] uwiedzenia. 50. +220 .

65. Nie [wolno] dręczyć sierot i wdów. 64. - 256. 
69. Nie [wolno] przeklinać sędziego. 75. - 315. Ani po hebrajsku, ani w żadnym innym jezzyku.

74. Nie[wolno] wystuchiwać skargi [jednej] strony, gdy nie [dzieje się to] wobecności [strony] przeciwnej. 80. - 281.

76. Nie [wolno] przychylić się jednym głosem za większościa w sprawie kary śmierci. 82. - 282. Wyrok śmierci nie mógł zapaść przewaga jednego głosu, musiały być przynajmniej dwa głosy.

78. Przykazanie skłaniania się [za opinia] większości. 66. + 175. W sporze pomiędzy dwoma grupami ludzi jednakowo uczonych w Torze, należy skłonić się za opinia większości, ale jeśli grupa mędrców Tory jest w mniejszości, to ich opinia przeważa nad duża grupa nieuczonych ludzi.

79. Nie [wolno] litować się nad biedakiem w sądzie. 84. - 277. Należy traktować obie strony równo.

80. Przykazanie uwolnienia od ciężaru. 68. + 202. Należy pomóc rozładować zwierze, nawet za darmo, podczas gdy za pomoc przy załadowywaniu można żądać zaptaty.

81. Nie [wolno] naginać wyroku [przeciwko] grzesznikowi, z powodu [wiedzy] o jego grzeszności. 85. - 278.

82. Nie [wolno] wydać wyroku [w oparciu] o przypuszczalna wiedzę. 86. - 290. W sprawach o kare śmierci musiało być dwóch świadków, którzy widzieli zbrodnie jednocześnie.

83. Nie [wolno] przyjąć łapówki. 87. - 274. Nawet w postaci pochlebnych stów.

\section{Z Księgi WAJIKRA (LEVITICUS)}

120. Przykazanie złożenia ofiary przez sąd, który pomylił się w decyzji. 119. +86 .

122. Przykazanie [składania] świadectwa. 121. + 178. Musiało być dwóch świadków, którzy mieli obowiązek znać cała prawdę.

130. Przykazanie zwrotu tego co zrabowane. 132. + 30. Należy zwrócić skradziony przedmiot; niemożliwość zwrócenia tego konkretnego przedmiotu to dodatkowe wykroczenie, oprócz samej kradzieży.

167. Nie zje nieczysty z ofiar. 172. - 129. Kto jest nieczysty, oczyszcza sie przez zanurzenie w mykwie i odczekuje do zachodu słońca.

169. Przykazanie [dotyczace] nieczystości [kogoś, kto jest] mecora. 169. + 101. Mecora to ktoś cierpiacy na pewna chorobę skórna caraat (nie jest pewne, czy byt to trad).

170. Nie wolno golić włosów na liszaju. 173. - 307. Włosów na brodzie kogoś, kto byt chory na caraat, żeby kapłan mógł rozpoznać oznaki choroby.

171. Przykazanie [dotyczace] rozwichrzenia włosów i rozdarcia ubrań. 170. + 112. Przez kogoś, kto był mecora. Musiał on także mieszkać poza murami miasta.

172. Przykazanie [dotyczace śladów] plagi na ubraniu. 171. + 102. Caraat mogło pojawić się też na materiałach, lub skórze. Po przekazani ich kapłanowi należało je spalić. 
173. Przykazanie [dotyczace] oczyszczenia z caraat [przez kropienie] hizopem. 174. + 110. Ta micwa odnosi się do rytuału oczyszczenia, przez który przechodzit człowiek, który wyleczył się z caraat. Hizop to gałąka dzikiego krzewu, używana do kropienia.

174. Przykazanie [dotyczace] ogolenia [tego, kto był] mecora. 175. + 111.

175. Przykazanie zanurzenia się przez nieczystego. 176. + 109. W mykwie w celu oczyszczenia rytualnego.

177. Przykazanie [dotyczace] nieczystości domu, w którym jest plaga. 178. + 103. (...).

178. Przykazanie [dotyczące] nieczystości zaw - mężczyzny mającego upławy (wycieki). 179. + 104. Sam był nieczysty i mógł zanieczyszczać innych. Gdy wycieki się skończyły - oczekiwat siedem dni i szedł do mykwy.

180. Przykazanie [dotyczace] nieczystości mężczyzny mającego polucję. 181. + 105. Sam jest nieczysty i może zanieczyszczać innych, oczyszcza się przez mykwę.

181. Przykazanie [dotyczace] nieczystości kobiety [w okresie] nida. 182. + 99. Okres nida trwa od poczatku menstruacji i przez siedem dni do zakończenia krwawienia. W tym czasie kobieta jest nieczysta rytualnie, po tym okresie oczyszcza sie przez mykwę.

182. Przykazanie [dotyczace] nieczystości zawa - kobiety mające uptawy (wycieki). 183. + 106. Zob. mc. 178.

187. Przykazanie przykrycia krwi. 186. + 147. Po zabiciu zwierzęcia dzikiego, jego krew trzeba przykryć ziemia z góry i z dołu. Dotyczy to ptactwa, ale nie zwierząt domowych.

188. Nie [wolno] zbliżać się do ani jednej ze wszystkich [zakazanych] nagości. 189. - 353. Do żadnej z zakazanych kobiet. Zasada jichud nie pozwalała mężczyźnie przebywać w jednym, zamkniętym pomieszczeniu z kobieta, która nie jest jego żona bądź bliską krewną.

189. Nie [wolno] odstaniać nagości ojca. 190. - 351.

190. Nie [wolno] odstaniać nagości matki. 191. - 330.

191. Nie [wolno] odsłaniać nagości żony ojca. 192. - 332. Nawet po śmierci ojca.

192. Nie [wolno] odstaniać nagości siostry. 193. - 331.

193. Nie [wolno] odstaniać nagości córki syna. 194. - 334.

194. Nie [wolno] odstaniać nagości córki córki. 195. - 335.

195. Nie [wolno] odstaniać nagości córki. 196. - 336.

196. Nie [wolno] odstaniać nagości siostry ze strony ojca. 197. - 333. Siostry przyrodniej - od innej matki.

197. Nie [wolno] odstaniać nagości siostry ojca (ciotki). 199.- 341.

198. Nie [wolno] odstaniać nagości siostry matki. 198. - 340.

199. Nie [wolno] odstaniać nagości brata ojca. 200. - 352.

200. Nie [wolno] pójść do żony brata (stryjenki). 201. - 342. Rabini dodawali również: do żony brata matki. Słowo „pójść" jest eufemizmem na stosunek.

201. Nie [wolno] pójść do synowej. 205. - 343. 
202. Nie [wolno] pójść do żony brata. 202. - 344.

203. Nie [wolno] pójść do kobiety i jej córki. 203. - 337.

204. Nie [wolno] odstaniać nagości kobiety i córki jej syna. 204. - 338.

205. Nie [wolno] odsłaniać nagości kobiety i córki jej córki. 206. - 339.

206. Nie [wolno] pójść do dwóch sióstr żyjących. 207. - 345. Nawet po rozwodzie z pierwsza siostra. Można dopiero po śmierci tej pierwszej.

207. Nie [wolno] pójść do kobiety w czasie gdy jest nida. 208. - 346.

209. Nie [wolno mężczyźnie] mieć stosunków z mężczyzną. 210. - 350. Dosłownie „potaczyć się".

210. Nie [wolno] połaczyć się ze zwierzęciem. 211. - 348. Mieć stosunków.

211. Nie położy się kobieta ze zwierzęciem. 212. - 349.

212. Przykazanie, aby bać się ojca i matki. 213. + 211.

216. Nie [wolno] żą́ skrajów pola 229. - 210. Wszyscy (także kapłani i lewici) pozostawiali pea - skraje pola nie zżęte - dla biedaków.

218. Nie [wolno] zbierać kłosów, które spadły podczas żniw. 230. - 211.

219. Przykazanie [dotyczace] kłosów, które wypadły (leket). 215. + 121. Kłosów, które wypadty spod sierpa podczas żęcia, lub z ręki podczas zbierania. Jeden lub dwa kłosy, które wypadty to leket, jeśli z ręki właściciela wypadna trzy lub więcej kłosów jednorazowo, to nie jest to leket - właściciel może je zebrać.

220. Nie [wolno] zrywać olelot (zbyt matych kiści winogron) w winnicy. 231. 212. Kiście winogron, mające mniej niż przeciętnie to tzw. olelot, pozostawiane byty dla biednych, nie zebrane.

222. Nie [wolno] zbierać opadtych winogron. 232. - 213. (...). Jest to traktowane jak okradanie biednych.

224. Nie [wolno] kraść żadnej rzeczy. 233. - 244. Nie wolno też pomagać w kradzieży, ani kupować kradzionych rzeczy.

225. Nie [wolno] wypierać się pieniędzy cudzych [powierzonych] w ręce. 234. - 249. Nie wolno wypierać się dtugów, ani pieniędzy powierzonych do pilnowania. Człowiek, który się tego dopuszcza, nie może być świadkiem.

226. Nie [wolno] przysięgać zaprzeczając [w sprawie] pieniędzy. 235. - 248. Nie wolno przysiegać, że nie dostało się pożyczki lub depozytu.

227. Nie [wolno] przysięgać fatszywie. 236. - 61.

228. Nie [wolno] odmawiać [oddania rzeczy należącej do kogoś innego]. 237. 247. 229. Nie [wolno] rabować. 238. - 245. Kto obrabowat jawnie - zwracat tyle ile ukradt, kto ukradt skrycie - zwracat podwójnie, ponieważ ten, kto kradnie w ukryciu, bardziej boi się ludzi niż widzacego wszystko Boga.

230. Nie [wolno] opóźniać zapłaty najemnikowi. 239. - 238.

231. Nie [wolno] przeklinać żadnego człowieka. 240. - 317. Ani w obcym języku, ani gdy przeklinany nie styszy. Ani nawet siebie samego.

232. Przed niewidomym nie postawisz przeszkody. 241. - 299. W treści tej micwy zawiera się też idea, że nie wolno nikogo zwodzić, ani w słowach ani czynem; ani 
w sprawach duchowych, ani w sprawach światowych, niczym, co mogłoby spowodować smutek lub szkodę.

233. Nie [wolno] postępować nieuczciwie [w] sądzeniu. 242. - 273.

234. Nie [wolno] mieć w sądzie względów dla [człowieka] znamienitego. 243. - 275.

235. Przykazanie dla sędziego, aby osądzat sprawiedliwie. 218. + 177. Watpliwości rozstrzyga się na rzecz oskarżonego, a nie przeciwko niemu.

236. Nie [wolno] obmawiać. 244. - 301. Istnieja cztery rodzaje obmowy: (...) plotki, (...) mówienie o kimś źle lub z intencja zaszkodzenia mu, (...)mówienie o kimś nieprawdy, która go zniesławia; najgorsze z tych wszystkich rzeczy jest stuchanie, bo to stwarza mówiącemu okazję do grzechu.

237. Nie [wolno] stać [bezczynnie] wobec krwi bliźniego. 245. - 297. Gdy jego życie jest zagrożone. Ale nie ma obowiązku oddawania życia za kogoś.

238. Nie [wolno] nienawidzić swojego brata. 246. - 302. Nie wolno nienawidzić go w chciwości. Kto nienawidzi otwarcie przekracza micwy; 241, 242 i 24.

239. Przykazanie udzielania napomnień. 219. + 205. Sa trzy stopnie napomnień: w osobności, wobec przyjaciót, publicznie.

240. Nie [wolno] zawstydzać oblicza [bliźniego]. 247. - 303. Zawstydzanie publiczne jest jak morderstwo.

241. Nie [wolno] się mścić. 248. - 304.

242. Nie [wolno] chować urazy. 249. - 305.

243. Przykazanie kochania bliźniego swojego jak siebie samego. 220. + 206.

244. Nie [wolno] parzyć bydła z innym gatunkiem. 250. - 206. Nie wolno krzyżować gatunkowo zwierząt i ptaków. Nie wolno zlecać takiego zadania nie-Żydowi; można natomiast korzystać z krzyżówki.

245. Nie [wolno] siać różnych gatunków (...). 251. - 215. Dotyczy to roślin jadalnych (zbóż, warzyw, roślin strączkowych) sianych jednocześnie na jednym polu. Można jednak sadzić na jednym polu drzewa i inna rośline jadalna. Nie wolno krzyżować drzew, wolno jednak korzystać z takiej krzyżówki.

248. Nie [wolno] jeść jak żarłok i pijak. 253. - 195.

249. Nie [wolno] wróżyć. 254. - 33. Nie wolno szukać "znaków”, wierzyć w zabobony itp.

250. Nie [wolno] wyznaczać [pomyślnych i niepomyślnych] pór. 255. - 32.

253. Nie [wolno] pisać na ciele napisów wyrytych. 258. - 41. Nie wolno robić tatuaży.

257. Przykazanie dotyczace szanowania mędrców. 223. + 209. Należy szanować mędrców Tory (talmide chachamim).

258. Nie [wolno] oszukiwać na wadze. 261. - 271. Nie wolno oszukiwać na mierzeniu towaru, ani w mierzeniu ziemi.

259. Przykazanie, aby [mieć] uczciwe wagi i odważniki. 224. + 208.

260. Nie [wolno] przeklinać ojca i matki. 252. - 318. Nawet po ich śmierci. 
291. Nie [wolno] kastrować niczego. 312. - 361. Ani człowieka, ani zwierzęcia, ani ptaka. Nie wolno też sterylizować.

294. Nie [wolno] zarżnać zwierzęcia i jego młodego w tym samym dniu. 314. 101. Nie ważne, które zabijano pierwsze. Nie dotyczyło to ptaków.

336. Przykazanie rozsadzenia między sprzedajacym a kupujacym, 330 +245.

337. Nie [wolno] oszukiwać w transakcjach handlowych. 341. - 250. Nie wolno oszukiwać klienta, który jest nieświadomy co do prawdziwej wartości towaru.

343. Nie [wolno] oszukiwać na procentach. 342. - 235. Nie wolno pożyczać na procent innemu Żydowi.

344. Nie [wolno], obarczać niewolnika praca poniżajaca. 346. - 257. (...).

345. Nie będzie sprzedany niewolnik [żydowski] na licytacji niewolników. 347. -258 .

346. Nie będzie wykonywat [niewolnik żydowski] pracy uciążliwej. 348. - 259. Nie wolno było zlecać mu prac niepotrzebnych, po to tylko, by był zajęty.

\section{Z Księgi BAMIDBAR (NUMERI)}

387. Nie [wolno] zwracać się za myślami serca i za oczami. 388. - 47. Nie wolno zajmować się myślami heretyckimi i zwracać oczy ku niemoralności.

406. Przykazanie dotyczące unieważnienia ślubów. 407. + 95. Według prawa Tory istnieje (...) - unieważnienie (oficjalne) własnego ślubu; (...) - unieważnienie przez męża lub ojca, ślubu uczynionego przez kobietę - jeśli anuluje go w chwili, gdy się o nim dowie.

407. Nie złamie się stowa [danego] w ślubach. 408. - 157.

409. Nie [wolno] zabić mordercy, zanim postawi się go przed sądem. 411. - 225.

411. Nie będzie wydawat wyroku świadek w sprawie, w której świadczyt. 412. - 291. W sprawach o karę śmierci świadek nie mógł podawać argumentów za, czy przeciw. W sprawach o pieniądze świadek mógł przedstawić argumenty, ale nie mógt sądzić. W sprawach, gdzie Tora nie nakazuje świadkowi stawić się obowiąkowo mógł on być także i sędzia.

412. Nie [wolno] wziać wykupienia za skazanego na śmierć. 413. - 295. Za życie mordercy skazanego na śmierć.

413. Nie [wolno] wziać wykupienia od skazanego na wygnanie. 414. - 296. Nie można było wykupić się od wygnania do miasta ucieczki.

\section{Z Księgi DEWARIM (DEUTERONOMIUM)}

414. Nie [wolno] mianować sędziego, który nie jest biegły w sądzeniu. 415. - 284. Nie wyznacza się na sędziego kogoś, kto nie jest biegły w Torze, nawet, jeśli ma wielki charakter, lub jest biegly w innych naukach.

415. Nie [wolno] sędziemu bać się człowieka groźnego. 416. - 276. Strach przed oskarżonym mógłby wptynać na wyrok; sędzia może się wycofać tylko przed przystapieniem do sądzenia. 
416. Nie [wolno] pożądać rzeczy należacej do [kogoś] innego. 425. - 266. Ta micwa różni się od mc. 38 w tym, że dotyczy pożądania bez podejmowania prób zdobycia przedmiotu pożądania.

434. Przykazanie [aby] dołaczyć się do mędrców. 433. + 6. Należy przyłaczyć się do mędrców Tory, by jak najwięcej się od nich nauczyć. Dobrze jest ożenić się z córka uczonego i własne dzieci wydać za mąż za uczonych.

452. Nie [wolno ] jeść członków ze [zwierzęcia] żyjącego. 465. - 182. (...).

463. Przykazanie, aby przestuchiwać świadków dobrze. 443. + 179. (...).

467. Nie [wolno robić] sobie nacięć. 477. - 45. Nie wolno nacinać na ciele, tak jak robia to batwochwalcy. W zakres tej micwy wchodzi też prawo, że dwa sądy w jednym mieście nie moga wydawać wyroków idących za dwoma różnymi zwyczajami; tak samo należacy do jednej gminy powinien mieć jednakowe prawo.

478. Nie [wolno] odmawiać [środków] do życia biedakowi. 483. - 232. Zwłaszcza krewnemu i ludziom z własnego miasta.

479. Przykazanie cedaki (dobroczynności). 450. + 195. Cedaka - dobroczynność - jest obowiąziem religijnym.(...).

481. Nie wolno odsyłać niewolnika [żydowskiego] z pustymi rękami. 485. - 233.

482. Przykazanie wyposażenia niewolnika [żydowskiego]. 451. + 196. Gdy niewolnik został uwolniony, dostawat od właściciela dobrowolny dar o wartości minimum 30 sela.

491. Przykazanie mianowania sędziów i nadzorców. 491. + 176. Należy ustanowić sądy w każdej społeczności żydowskiej. (...).

521. Nie [wolno] zlitować się w sprawach karnych nad [wyrządzającymi] szkodę. 527. - 279. Nie wolno litować się sądowi nad skazanym.

522. Nie [wolno] przesuwać granicy. 525. - 246. Por. mc. 229.

523. Nie [wolno] wydać wyroku w oparciu o [świadectwo] jednego świadka. 526. - 288. Bez świadectwa dwóch świadków nie można zasadzać żadnej kary, ani grzywny, ani batów, ani kary śmierci. Wyjątek stanowia np. przypadki: gdy ktoś zaświadcza, że mąż kobiety nie żyje i może ona ponownie wyjść za mąż, w przypadku niewyjaśnionego morderstwa, gdy ktoś rozpoznaje morderce, gdy nie jest pewne, czy kawałek mięsa jest koszerny, czy nie.

525. Nie [wolno] przestraszyć się wroga na wojnie. 528. - 58.

529. Nie [wolno] wycinać drzewa owocowego podczas oblężenia. 530. - 57. Nie tylko podczas wojny, w ogóle nie wolno niszczyć bez celu drzew, ani innych przedmiotów.

537. Przykazanie pochowania zmartego. 534. + 231. (...).

538. Przykazanie zwrotu zguby. 535. + 204. Należy oddać znaleziona rzecz nawet o niewielkiej wartości. O znalezionej zgubie należy ogłosić publicznie i zaczekać aż zgłosi się właściciel. Jeśli jest to rzecz, która łatwo się psuje - można ja sprzedać i oddać pieniądze. 
539. Nie [wolno] „ukrywać się” przed zguba. 562. - 269. Nie wolno lekceważyć napotkanej zguby, należy ją zwrócić właścicielowi.

540. Nie [wolno] pozostać bezczynnym [gdy] bydło upadnie pod ciężarem. 563. -270 .

542. Nie będzie nosiła kobieta ozdób mężczyzny. 564. - 39. Kobiety nie moga nosić strojów mężczyzny; nie moga też iść na wojnę (uzbrojone) jak mężczyzna; nie moga się one przyłączyć do armii, nawet jeśli nie noszą broni [rzadko w dziejach przestrzegano, w historii państwa Izrael nie stosowano - K.W.].

543. Nie będzie nosił mężczyzna ozdób kobiety. 565. - 40. Mężczyzna nie może nosić strojów kobiecych, ani upodabniać się do kobiet (farbując włosy, noszac biżuterię kobieca itp.).

544. Nie [wolno] wziać matki [ptaka] razem z [jej] młodymi. 566. - 306. Nie wolno zabrać z gniazda samicy siedzacej z młodymi (lub wysiadujacej jajka).

545. Przykazanie wypuszczenia [samicy ptaka] z gniazda. 537. + 148. Należy ja wypuścić wolno, przed zabraniem z gniazda jej młodych (lub jajek). Dotyczy to tylko ptaków koszernych i tylko w gnieździe napotkanym przypadkowo, nie będących niczyja własnością.

546. Przykazanie grodzenia dachu. 538. + 184. Wtaściciel domu ma obowiazzek zrobić na dachu ogrodzenie, by zapobiec wypadkom.

547. Nie [wolno] zostawiać przeszkody w domu. 567. - 298. Nie wolno zostawiać żadnego niebezpiecznego przedmiotu na nie swoim terenie.

552. Przykazanie poślubienia kobiety. 539. + 231. Należy poślubić kobietę zgodnie z prawami Tory, dając jej ketubę (kontrakt małżénski).

553. Przykazanie dla zniestawiającego [kobiete], że poślubi ja na zawsze. 540. + 219. Kto fałszywie oskarżyt żonę o cudzołóstwo (...) nie może się z nia rozwieść.

554. Nie rozwiedzie się zniesławiający żonę. 572. - 359.

556. Nie [wolno] ukarać zmuszonego do grzechu. 573. - 294.

557. Przykazanie [że] uwodziciel poślubi uwiedziona. $542+218$. W czasach Bet Hamikadasz, dodatkowo płacit on ojcu dziewczyny 50 szekli srebrnych.

558. Nie rozwiedzie się uwodziciel ze swoja ofiara. 588. - 358.

574. Nie [wolno] opóźniać [spetnienia] ślubów i zobowiązań. 586. - 55. (...).

575. Przykazanie, aby dotrzymywać [tego] co wyszło z ust. 546. + 94. Należy wypetniać dane słowo.

576. Przykazanie, aby najemnik jadt w czasie swojej pracy. 547. + 201. Najemnik pracujacy przy pracach rolnych (zrywanie, zbieranie, przerób itp.), może jeść produkt, przy którym pracuje (i tylko ten produkt), w chwilach przerw w wykonywaniu pracy (...) (nie jego rodzina).

579. Przykazanie [dotyczace] rozwodu z kobieta. 548. + 222. Kto rozwodzi się z żona, musi to zrobić zgodnie z prawami Tory: wręczajac jej dokument rozwodowy get, dobrowolnie, przy dwóch świadkach. Od czasów Rabina Gerszoma z Moguncji, do rozwodu potrzebna jest zgoda kobiety [X/XI w. - K.W.]. 
580. Nie wróci rozwiedziony do rozwiedzionej swojej [żony] po tym jak poślubiła [innego]. 590. - 356. Jeśli kobieta po rozwodzie poślubiła innego i rozwiodła się z nim, lub owdowiała, to pierwszy mąż nie może jej powtórnie poślubić.

581. Nie [wolno] powoływać do wojska nowożeńca, przez cały pierwszy rok. 591. - 311. (...). Nie powinien też opuszczać w tym roku żony na dtu̇̇szy czas.

582. Przykazanie, aby radowat swoja żone przez pierwszy rok. 549. - 214. Przez pierwszy rok po ślubie. Micwa ta nie dotyczy tego, kto poślubia ponownie żonę, z którą się rozwiódt.

585. Nie [wolno] brać w zastaw [rzeczy] dłużnika siła. 594. - 239. (...).

586. Nie [wolno] przetrzymywać zastawu w czasie, gdy jego wtaściciel go potrzebuje. 595. - 240. Np. ubrania na noc.

587. Przykazanie zwrócenia zastawu jego właścicielowi w czasie, gdy go potrzebuje. 550. +199 .

588. Przykazanie [że] „w dniu [skończy pracę] dasz mu jego zapłatę". 551. + 200. Człowiek wynajęty na dzień - może żąać zapłaty po zachodzie słońca; człowiek wynajęty na noc - przed zachodem słońca następnego dnia. (...).

589. Nie będzie świadczyt krewny. 596. - 287. Ani w sprawach o pieniądze, ani w sprawach o karé śmierci. Ani oskarżając, ani broniąc. Dotyczy to wszystkich, którzy maja prawa do dziedziczenia w danej sprawie.

590. Nie [wolno] naruszać prawa konwertyty i sieroty. 597. - 208.

591. Nie [wolno] zajmować [rzeczy] wdowy. 598. - 241. Posłaniec bet dinu (sadu) nie może brać zastawu od wdowy (...) dotyczy to każdej wdowy i bogatej i biednej.

593. Przykazanie pozostawienia zapomnianego snopa. 552. + 122. Gdy ktoś zapomniat zabrać z pola jeden lub dwa snopy, o wadze nie większej niż dwa sea - to zostawiat je dla biednych. Jeśli zapomniał o trzech lub więcej snopach, to nie musiat ich zostawić.

593. Nie [wolno] zabierać snopa zapomnianego. 599. - 214. Dotyczy to także innych płodów rolnych.

596. Nie będzie się zawiązywać [pyska] zwierzęcia w czasie pracy. 601. - 219. Nie wolno krzyczé́ na zwierze, gdy podjada w czasie pracy.

600. Przykazanie, aby uratować ściganego. 556. + 247. Należy ratować kogoś, kogo ściga morderca, nawet, jeśli trzeba zabić mordercę.

601. Nie [wolno] litować się nad ścigającym. 603. - 293. Jeśli ktoś kogoś ściga, aby go zabić, należy zapobiec morderstwu, nawet jeśli wiąże się to z zabiciem (potencjalnego) mordercy. Jeśli morderstwo zostało już dokonane - to nie wolno wymierzać kary samowolnie, należy oddać sprawę w ręce bet dinu [sądu - K.W.].

SZEWA MICWOT BNEI NOACH - Siedem Przykazań [dla] potomków Noego

1. [Zakaz] jedzenia członków z żyjącego zwierzęcia. (Mc. 452).

3. [Zakaz] rabowania. (Mc. 224 i 228).

4. [Nakaz] ustanowienia sądów. (Mc. 58 i 491). 
6. [Zakaz] niemoralnych stosunków cielesnych. (Mc. 35).

7. [Zakaz] mordowania (dost. rozlewu krwi). (Mc. 34).

Przykazania judaizmu - micwy - zawierają znaczenia aksjologiczne i wyrażają je w formie kategorycznego wymogu ich przestrzegania. Stanowiły one w edukacji rabinicznej, talmudycznej i w powszechnym nauczaniu żydowskim, w tym szkolnym dzieci w chederze i młodzieży w jesziwie, podstawę kształtowania postępowań własnych oraz zachowań społecznych, nie tylko dotyczących wewnątrz wspólnoty wyznaniowej judaizmu. Zawierają się one również obecnie $\mathrm{w}$ jawnym rodowodzie edukacji $\mathrm{w}$ systemach niereligijnych. Współcześnie są one w większości (z wyjątkiem niektórych jednoznacznie religijnych) powszechnie obecne w kanonach wartości jako oczywiste, często mające dalsze uzasadnienia $w$ rezultatach poznania naukowego i rozwijających się praktykach przedmiotowych, w tym edukacyjnych, nie tylko doktrynalnie źródłowych dla judaizmu, lecz rozlegle przejawiających się w historycznie i współcześnie judeochrześcijańskim obszarze kulturowym.

W edukacji, zwłaszcza kształceniu i nauczaniu wychowującym, a takim ona była i nadal pozostaje, oraz $\mathrm{w}$ socjalizacji obu poziomów znajdujemy wartości z micwot o etycznym i jurydycznym sensie oraz przeznaczeniu ich stosowania. Wartości przykazań judaizmu zawierają wyraźne, a wiele z nich konkretne, nawet precyzyjne, odniesienia do motywowania człowieka oraz jego działania $\mathrm{w}$ tworzenie harmonii stosunków międzyludzkich. W narracjach znaczeniowych micwot nie występuje literalnie wyrażone słowo/pojęcie dobra, jednakże ich treści przekazują wręcz instruktywnie osiąganie równowagi, harmonijności, konsensusu, ładu w relacjach międzyludzkich z innymi istotami żywymi oraz spokoju wsobnego. Nie jest też wyrażane w przykazaniach judaizmu określenie zła - czym ono jest. Wiadomo jednak, czym byłoby zło, gdyby kategoryczny, wręcz konieczny wymóg spełnienia nakazu i zakazu nie został w motywie i czynie urzeczywistniony przez człowieka. Wartości wyrażane w micwot są normami orientującymi człowieka do aktywizmu osiągania rezultatu, skutku, efektu ponadindywidualnego, pojmowanego jako dobrostan wspólnotowo-społeczny oraz ekośrodowiskowy. Na wszystkich poziomach nauczania w szkołach żydowskich miał miejsce przekaz nauczający treści micwot oraz wymóg ich poznawania oraz stosowania - oczywiście w różnych zakresach treści nauczania, adekwatnie do szczebla edukacji, włącznie $\mathrm{z}$ ich studiowaniem $\mathrm{w}$ integralności $\mathrm{z}$ treściami talmudycznymi. W kształceniu i wychowaniu dyrektywalne znaczenia tarjag micwot wyznaczały w edukacji judaistycznej pragmatyczne cele i zadania, które przenikały $\mathrm{w}$ dziejach rozwoju intuicji i refleksji pedagogicznych do zewnętrznych kulturowo wobec niej społeczności i środowisk. 
Współcześnie we wspólnotowych społecznościach żydowskich, także w Izraelu, przestrzeganie treści i wartości tarjag micwot jest najogólniej zróżnicowane stanem świadomości i praktyki ortodoksyjnego judaizmu oraz modernizującego się tak zwanego otwartego, zwłaszcza przejawiającego się w konkretnych praktykach i sytuacjach, przeważnie względnego/relatywnego ich nieuwzględniania, czy częściowego stosowania. Jednakże, niezmienny pozostaje we wspólnotach żydowskich szacunek dla podstawowych wartości micwot, wyrażanych między innymi w zasadach wymaganych, dotyczących: higieny ciała i zdrowia, intymności ciała i związku małżeńskiego, edukacji dzieci i uczenia się, autorytetu i uznawania wiedzy, szacunku dla pracy i obowiązku zapłaty za nią, ochrony własności, wykonywania zobowiązań, powszechności i niezawisłości sądów, postępowania sprawiedliwego, miłosiernego, działania dobroczynnego i pomocowego, ochrony zwierząt i dobrostanu przyrodniczego, ciągłego i powszechnego szacunku wobec ludzi, $\mathrm{w}$ tym innych kulturowo i konfesyjnie. Jest to kulturowo trwały i aktualny potencjał aksjologiczny edukacji, zwłaszcza spełniający wymogi kształcenia oraz nauczania i wychowującego, który w nich przekazywany i utrwalany jest $\mathrm{w}$ życiu człowieka konieczny. Współczesne paradygmaty pedagogiki zawierają, często nie ujawniając historyczno-aksjologicznych źródeł swych obecnych cech tożsamościowych, zasoby wartości powstałych i istniejących w micwot, zwykle uznając je za genetycznie uniwersalistyczne.

Historia Żydów, od czasów późnego/schyłkowego hellenizmu, zwłaszcza ekspansji rzymskiej, szczególnie od okresu rozprzestrzeniania się islamu, następnie przez wielowiekowe czasy średniowiecza, a od XIX wieku w obu Amerykach aż do połowy XX wieku, tworzyła się w procesie rozwoju i funkcjonowania diasporowych (aszkenazyjskich i sefardyjskich) wspólnot. W różnych częściach Europy, Azji, Ameryki oraz Australii ich historia była możliwa dlatego, że społeczności żydowskie zachowały swoją podstawową odrębność kulturową, naznaczoną wyznawanymi i stosowanymi wartościami zawartymi w Ksieggach i Pismach kanonicznych judaizmu. Aksjologia judaizmu dawała jej wyznawcom siłę trwania i rozwoju w gospodarce przemysłowej, handlu, finansach, bankowości, a w dziedzinach nauki (matematyki, przyrodoznawstwa, medycyny) kierunek postępu intelektualnego oraz w kulturze muzycznej i sztuk plastycznych wyznaczających nowe poziomy artyzmu. Wartości tekstów judaizmu, zwłaszcza tarjag micwot, będące motywującymi działaniami, były jednocześnie regulatywnymi normami sankcjonującymi te działania. Sublimowały się one w aksjologii uniwersalnej społecznych cnót, takich jak: praca (gospodarka), edukacja (szkolnictwo), nauka (badania poznawcze), tworzenie prawa nowożytnego, twórczości artystyczne. Aksjologia judaizmu, mimo oczywistego jej rygoryzmu, sprzyjała na tyle koniecznej kulturowej stygmatyzacji życia wspólnotowego żydów, aby ich skuteczne 
funkcjonowanie znajdowało się $\mathrm{w}$ podstawowych nurtach życia społeczności państwowych, wielo- i monoetnicznych. Istniejące $\mathrm{w}$ diasporowych dziejach wspólnot żydowskich okresy ich gettoizacji nie wynikały z hermetyzmu aksjologicznego judaizmu, lecz $\mathrm{w}$ większości $\mathrm{z}$ konkretno-historycznych sprawstw powodowanych przez dominujące większości innych etnicznie kulturowych społeczności. Przy tym, odbywał się historycznie i kulturowo przebiegający transfer wartości, zwłaszcza pragmatycznych oraz normatywnych, z aksjologii judaizmu na zewnątrz, w procesie ich adaptacji do systemów normatywnych innych kulturowo i konfesyjnie większości społecznych, stanowiąc w cywilizcji śródziemnomorskiej i jej judeochrześcijańskim rozprzestrzenianiu się od czasów nowożytnych, swoistą kulturową wartość dodana, a w kanonach innokulturowych nadal będąc wzorcem i naśladowaniem, także współcześnie.

\section{BIBLIOGRAFIA}

Boska pieczęć. Mądrości Talmudu, wybór i przekł. z hebrajskiego A. Klugman, Wydawnictwo Europa, Wrocław 2000.

Stownik wyrazów obcych PWN, red. J. Tokarski, Państwowe Wydawnictwo Naukowe, Warszawa 1971.

Tarjag micwot 613 przykazań judaizmu oraz siedem przykazań rabinicznych i siedem przykazań dla nie-Żydów, przekł. E. Gordon, Fundacja Ronalda S. Laudera, Kraków 2000.

Z mądrości Talmudu, wybór i przekł. Sz. Datner, A. Kamieńska, Państwowy Instytut Wydawniczy, Warszawa 1988. 